\title{
PENGAWASAN PERIZINAN OLEH KOMISI PENYIARAN INDONESIA DAERAH (KPID) PROPINSI BANTEN UNTUK TV SWASTA LOKAL
}

\author{
ANDRIANSYAH, TAUFIQUROKHMAN, EVI SATISPI, \\ ${ }^{1,2}$ Fakultas Ilmu Sosial dan Ilmu Politik Universitas Prof.Dr. Moesopo (Beragama), \\ Jalan Hanglekir I No 8 Jakarta, Indonesia \\ 3 Fakultas Ilmu Sosial dan Ilmu Politik Universitas Muhammadiyah Jakarta, Jl. KH. \\ Ahmad Dahlan, Ciputat, Cireundeu, Ciputat Team., Jakarta Selatan. Indonesia \\ E-mail: \\ andriansyah@dsn.moestopo.ac.id ${ }^{1}$ and taufiqurokhman@dsn.moestopo.ac.id ${ }^{2}$ \\ and evi.satispi@umj.ac.id ${ }^{3}$
}

\begin{abstract}
Licensing is the main thing about broadcasting arrangements. In a series of broadcasting regulatory process stages, licensing becomes the decision stage of the state (through KPI and KPID) to provide an evaluation (evaluation) whether a broadcasting agency is eligible to be granted or eligible to continue lease rights over the frequency.

Indonesia Regional Broadcasting Commission or KPID is an independent state institution in Indonesia established in each province functioning as a regulator of broadcasting in every province in Indonesia. KPID is an institution capable of controlling the media, especially concerning Broadcasting Permit.

License of Broadcasting (IPP) is the right granted by KPID to broadcasters to conduct broadcasting. To date there are seven local private television broadcasters in Banten Province (1.Untirta TV; 2. Baraya TV; 3. CTV Banten; 4. TV3 Tangerang; 5. CCNC; 6. Carlita TV; 7. CTV Network) broadcasting to obtain broadcasting licenses.

The results of the study said that in the level of requirements that must be met by local private television broadcasters to obtain IPP, KPID has performed its duties optimally. KPID is always proactive towards local private television broadcasting institutions especially in guiding to complete the necessary conditions so that local TV in Banten Province can meet the requirements needed to manage IPP.

However, in the implementation of its role related to the phases of acquisition of IPP, KPID has not played an optimal role in performing its duties and functions. This is because in broadcasting there is still a violation by local private TV in broadcasting concerning the content of the broadcasting. In addition, in taking the policy, KPID is still intervened by the local government in the form of broadcast television broadcasting that is in accordance with local government requests, which KPID should not be interfered by any party considering KPID is an independent institution. So it can be concluded that KPID in general can not perform its duties and functions properly.
\end{abstract}

Kata kunci: KPID, Licensing, and Broadcasting Operating License 


\section{PENDAHULUAN}

Pedoman Perilaku Penyiaran dan Standar Program Siaran ini pada dasarnya dirancang berdasarkan amanat yang diberikan Undang-undang Republik Indonesia No. 32/2002, tentang Penyiaran kepada Komisi Penyiaran Indonesia. Dalam Pasal 8 UU tersebut dinyatakan bahwa Komisi Penyiaran Indonesia memiliki wewenang menetapkan Standar Program Siaran dan Pedoman Perilaku Penyiaran, serta memberikan sanksi terhadap pelanggaran Standar dan Pedoman tersebut.

Perilaku Penyiaran dan Standar Program Siaran ini dirancang dengan memperhatikan berbagai bentuk Kode Etik dan Standar Program yang telah dikembangkan oleh komunitas profesional dalam dunia penyiaran dan media massa di Indonesia selama ini, seperti: Kode Etik Wartawan Indonesia, Standar Profesional Radio Siaran serta Pedoman Program Penyiaran. Selain itu, Pedoman ini merujuk pada berbagai peraturan perundangan yang berlaku di Indonesia: Kitab Undang-undang Hukum Pidana, UU Pers, serta UU Perfilman.

Perkembangan teknologi komunikasi dan informasi telah melahirkan masyarakat informasi yang makin besar tuntutannya akan hak untuk mengetahui dan hak untuk mendapatkan informasi. Informasi telah menjadi kebutuhan pokok bagi masyarakat dan telah menjadi komoditas penting dalam kehidupan bermasyarakat, berbangsa, dan bernegara. Untuk televisi, TVRI (Televisi Republik Indonesia) adalah stasiun televisi pertama yang mengudara di Indonesia. Pertama siaran pada 17 Agustus 1962, TVRI menjadi salah satu proyek ambisius dari Soekarno yang pada waktu itu menginginkan agar negerinya tidak disebut terbelakang dan ketinggalan zaman, dan TVRI saat itu diproyeksikan untuk menyongsong pelaksanaan Asian Games IV yang merupakan pesta olahraga pertama yang diselenggarakan Indonesia. Kemudian, pada dekade 1990-an muncul televisi swasta yang di pelopori RCTI. Lalu TPI, SCTV, ANTV dan Indosiar. Stasiun-stasiun tersebut pada dasarnya merupakan salah satu pengembangan usaha dari keluarga Soeharto yang dalam segi bisnis memang menguasai ruang usaha di Indonesia. Dalam perkembangannya televisi-televisi, khususnya televisi swasta yang ada, secara geografis tersentral di Ibukota Jakarta, 
antara lain RCTI, TPI, SCTV, ANTV, Indosiar, Trans TV, TV 7, Lativi, Global TV dan Metro TV. Semuanya mempunyai hak siar secara nasional. Posisi Jakarta sebagai pusat pertelevisian nasional menjadi fenomena tersendiri bagi kualitas televisi itu sendiri, seperti pada munculnya penggeneralisasian budaya dan program siaran. Banyak acara ataupun sinetron televisi yang mengambil latar kota Jakarta karena selain tidak memakan ongkos produksi yang mahal juga dapat dikemas secara cepat dan efisien.

Setelah televisi swasta nasioanal, yang cukup menarik adalah munculnya televisi lokal. Terlepas dari konflik kepentingan antara pemerintah dan kapitalisme industri pertelevisian yang ada, tv lokal lahir dengan gairah otonomi daerah yang ada. Semangat untuk menjadi media lokal yang memfasilitasi masyarakat daerah masingmasing, baik dari segi informasi ataupun hiburan seakan menjadi jargon yang memposisikan TV lokal sebagai prospek cerah bagi kemajuan dunia media di Indonesia. Di wilayah Jakarta muncul Jak-TV, O-Chanel dan Space-Toon. Di Bandung, di warnai dengan kelahiran Bandung TV, S-TV, Padjajaran TV, CT Chanel. Kemudian di wilayah lainnya seperti Jogja TV (Yogyakarta), Bali TV (Denpasar), Pro TV (Semarang), J-TV (Surabaya) sebagai produk Jawa Pos. (http:// deniborin. multiply. com/journal/item/40/TV_Lokal_dan_Isu_Lokal diakses tanggal 12 Desember 2010). Perkembangan teknologi komunikasi dan informasi tersebut telah membawa implikasi terhadap dunia penyiaran, termasuk penyiaran di Indonesia. Penyiaran sebagai penyalur informasi dan pembentuk pendapat umum, perannya makin sangat strategis, terutama dalam mengembangkan alam demokrasi di negara kita. Penyiaran telah menjadi salah satu kegiatan berkomunikasi bagi masyarakat, lembaga penyiaran, dunia bisnis, dan pemerintah.

Satu dari media massa modern yang kini sangat pesat perkembangannya ialah televisi. Televisi merupakan media alternatif untuk mencari informasi maupun untuk memenuhi kebutuhan masyarakat lainnya sebagai fungsi dari komunikasi dan juga media yang atraktif dibandingkan dengan media massa modern lainnya. Dikarenakan memiliki keunikan tersendiri yang merupakan penggabungan antara prinsip 'tele' yang terdapat pada radio (pendengaran/audio) serta prinsip 'visi' yang terdapat dalam film (penglihatan/visual), sehingga mampu menarik perhatian khalayak. 
Di Propinsi Banten sendiri terdapat tujuh televisi lokal, yaitu Radar TV, Tegar TV, Krakatau TV, dan Siger TV. Televisi lokal tersebut sudah mulai bersiaran dan jangkauan siarannya pun cukup luas. Dalam dunia penyiaran khususnya penyiaran televisi perlu adanya pengawasan dari suatu lembaga. Pengawasan terhadap lembaga penyiaran sangat penting khususnya pengawasan pada izin siaran karena saat ini ada beberapa lembaga penyiaran khususnya televisi yang sudah melakukan siaran namun belum memilki izin siaran. Dengan adanya pengawasan tersebut maka lembaga penyiaran. Khususnya televisi yang belum memiliki izin siaran dapat ditertibkan. Komisi Penyiaran Indonesia adalah lembaga negara yang bersifat independen mengatur hal-hal penyiaran yang ada di pusat dan di daerah yang tugas dan wewenangnya diatur dalam Undang-undang Nomor 32 Tahun 2002, sebagai wujud peran serta masyarakat di bidang penyiaran. Dalam menjalankan fungsi, tugas, wewenang dan kewajibannya, KPI Pusat diawasi oleh Dewan Perwakilan Rakyat Republik Indonesia, dan KPI Daerah diawasi oleh Dewan Perwakilan Rakyat Daerah Provinsi. KPI mempunyai tugas dan kewajiban :

a. menjamin masyarakat untuk memperoleh informasi yang layak dan benar

b. sesuai dengan hak asasi manusia;

c. ikut membantu pengaturan infrastruktur bidang penyiaran;

d. ikut membangun iklim persaingan yang sehat antar lembaga penyiaran dan

e. industri terkait;

f. memelihara tatanan informasi nasional yang adil, merata, dan seimbang;

g. menampung, meneliti, dan menindaklanjuti aduan, sanggahan, serta kritik dan

h. apresiasi masyarakat terhadap penyelenggaraan penyiaran; dan

i. menyusun perencanaan pengembangan sumber daya manusia yang menjamin

j. profesionalitas di bidang penyiaran.

Undang-undang Penyiaran No 32 Tahun 2002 merupakan dasar utama bagi pembentukan Komisi Penyiaran Indonesia. Semangatnya adalah pengelolaan sistem penyiaran yang merupakan ranah publik harus dikelola oleh sebuah badan independen yang bebas dari campur tangan pemodal maupun kepentingan kekuasaan. Berbeda dengan semangat dalam Undang-undang penyiaran sebelumnya, yaitu Undang-undang 
No. 24 Tahun 1997 pasal 7 yang berbunyi "Penyiaran dikuasai oleh negara yang pembinaan dan pengendaliannya dilakukan oleh pemerintah", menunjukkan bahwa penyiaran pada masa itu merupakan bagian dari instrumen kekuasaan yang digunakan untuk semata-mata bagi kepentingan pemerintah. Sejak disahkannya Undang-undang No. 32 Tahun 2002 terjadi perubahan fundamental dalam pengelolaan sistem penyiaran di Indonesia, dimana pada intinya adalah semangat untuk melindungi hak masyarakat secara lebih merata.

Perubahan paling mendasar adalah adanya limited transfer of authority dari pengelolaan penyiaran yang selama ini merupakan hak ekslusif pemerintah kepada sebuah badan pengatur independen (independent regulatory body) bernama Komisi Penyiaran Indonesia (KPI). Independen yang dimaksudkan adalah untuk mempertegas bahwa pengelolaan sistem penyiaran yang merupakan ranah publik harus dikelola oleh sebuah badan yang bebas dari intervensi modal maupun kepentingan kekuasaan. Komisi Penyiaran Indonesia Daerah atau KPID adalah sebuah lembaga negara independen di Indonesia yang didirikan di setiap provinsi berfungsi sebagai regulator penyelenggaraan penyiaran di setiap provinsi di Indonesia. Dasar hukum pembentukannya adalah Undang-undang Republik Indonesia Nomor 32 Tahun 2002 Tentang Penyiaran. KPID merupakan sebuah lembaga yang mampu menjadi kontrol terhadap media terutama menyangkut Izin Penyelenggaraan Penyiaran.

KPID sebagai lembaga negara tidak lepas eksistensinya dengan teknologi sistem informasi. Berbagai informasi strategis, taktis, dan operasional harus didasarkan pada informasi yang relevan dan andal atas sumber-sumber daya yang dimilikinya. Selama ini masalah perizinan pada televisi di Propinsi Banten hampir sama dengan permasalahan yang ada di daerah lainnya. Permasalahan yang sering dihadapi adalah mengenai kanal frekuensi siaran, dimana kanal yang tersedia bagi lembaga penyiaran khususnya televisi jumlahnya sangat terbatas, namun banyaknya stasiun televisi yang mengajukan permohonan kanal cukup banyak sehingga perlu dilakukan seleksi. Selain itu masalah yang lain adalah adanya beberapa lembaga penyiaran televisi swasta lokal di Propinsi Banten yang belum memiliki izin penyelenggaraan penyiaran sudah 
melakukan siaran. (Wawancara dengan Ade Mujaremi selaku Ketua KPID Propinsi Banten)

Dalam hal ini pengawasan yang dilakukan termasuk dalam pengawasan terhadap izin siaran keseluruhan atau dengan kata lain izin penyelenggaraan penyiaran (IPP). Penelitian ini penting untuk diteliti karena tujannya adalah supaya masyarakat mengetahui bagaimana kinerja dari KPID terutama dalam bidang perizinan pada televisi swasta lokal. Selain itu agar mayarakat yang akan mendirikan televisi bisa mengetahui bagaimana proses yang harus dilalui untuk memperoleh izin siaran.

Objek penelitian ini adalah KPID Provinsi Banten. Adapun alasan pemilihan lokasi tersebut karena KPID merupakan satu-satunya lembaga yang berfungsi mewadahi aspirasi masyarakat serta mewakili kepentingan masyarakat akan penyiaran. KPID mempunyai wewenang mengawasi pelaksanaan peraturan dan pedoman perilaku penyiaran dan standar program siaran, juga memberikan sanksi terhadap pelanggaran terhadap pedoman perilaku penyiaran dan standar program siaran.

\section{B. Rumusan Masalah}

Berdasarkan latar belakang diatas, maka penulis akan melakukan penelitian untuk mengetahui peranan Komisi Penyiaran Indonesia Daerah Provinsi Lampung dalam mengawasi izin penyelenggaraan penyiaran pada lembaga penyiaran televisi swasta lokal di Propinsi Banten yang meliputi :

1. Bagaimana peran KPID dalam mengawasi syarat-syarat yang harus dipenuhi lembaga penyiaran televisi swasta lokal untuk mendapatkan IPP?

2. Bagaimana peran KPID dalam mengawasi tahapan-tahapan yang harus dilalui lembaga penyiaran televisi swasta lokal dalam memperoleh IPP?

\section{TUJUAN PENELITIAN}

Tujuan Penelitian Sesuai dengan masalah penelitian diatas, maka tujuan yang ingin dicapai adalah untuk mengetahui peranan Komisi Penyiaran Indonesia Daerah Provinsi Banten dalam mengawasi izin penyelenggaraan penyiaran pada lembaga penyiaran televisi swasta lokal di Propinsi Banten. Selain itu tujuan dari 
penulisan penelitian ini adalah sebagai masukan sekaligus bisa menjadi pedoman perilaku penyiaran dan standar program siaran bagi para pemangku kepentingan termasuk bagi para akademisi yang memang menggeluti permasalahan KPID.

Adapun standar dari pedoman penyiaran adalah sebagaimana dinyatakan dalam pasal 3 UU Penyiaran 2002, dapat diwujudkan, yakni: “' . . memperkukuh integrasi nasional, terbinanya watak dan jati diri bangsa yang beriman dan bertakwa, mencerdaskan kehidupan bangsa, memajukan kesejahteraan umum, dalam rangka membangun masyarakat yang mandiri, demokratis, adil dan sejahtera. . . "

Sebagaimana diamanatkan pasal 48 UU Penyiaran 2002, Pedoman Perilaku Penyiaran ini disusun oleh Komisi Penyiaran Indonesia berdasarkan: nilai-nilai agama, moral, dan peraturan-perundangan yang berlaku, serta norma-norma lain yang berlaku dan diterima oleh masyarakat umum dan lembaga penyiaran.

\section{Kegunaan Penelitian}

Adapun kegunaan penelitian antara lain :

1. Secara teoritis dapat dijadikan referensi bagi penelitian lanjutan, khususnya bagi para akademisi yang ada kaitanya dengan peranan KPID dalam proses izin penyelenggaraan penyiaran pada lembaga penyiaran televisi swasta lokal.

2. Secara praktis, penelitian ini diharapkan dapat menjadi sumbangan pemikiran penulis sebagai bahan informasi dan pengetahuan bagi para akademisi dan para mahasiswa/i yang akan mengambil penelitian tentang peranan Komisi Penyiaran Indonesia Daerah Provinsi Banten dalam mengawasi izin siaran pada lembaga penyiaran televisi swasta lokal di Propinsi Banten.

\section{TINJAUAN TENTANG PERANAN KPID PROPINSI BANTEN}

\section{A. Tinjauan Tentang Peranan Media}

Peran media dalam pembentukan opini semakin pasif dalam beberapa dekade terakhir. Semakin pentingnya peran media dalam pembentukan opini publik tidak terlepas dari pesatnya peningkatan teknologi informasi dan komunikasi. Jika pada 10 tahun sebelumnya seseorang masih sulit untuk dapat mengakses internet, namun 
hari ini setiap orang dapat mengakses internet secara mobile. Jika 10 tahun sebelumnya jumlah stasiun televisi sangat terbatas, namun hari ini jumlah stasiun televisi semakin banyak dan dengan tingkat coverage yang lebih luas. Bahkan, hari ini kita dapat mengakses jaringan internasional, sesuatu yang mustahil dilakukan pada beberapa tahun yang lalu. Peranan media masa tersebut tentunya tidak dapat dilepaskan dari arti keberadaan media itu sendiri.

Dengan peran tersebut, media massa menjadi sebuah agen dalam membentuk citra di masyarakat. Pemberitaan di media massa sangat terkait dengan pembentukan citra, karena pada dasarnya komunikasi itu proses interaksi sosial, yang digunakan untuk menyusun makna yang membentuk citra tersendiri mengenai dunia dan bertukar citra melalui simbol-simbol. Dalam konteks tersebut, media memainkan peranan penting untuk konstruksi realitas sosial. Seperti kita ketahui, media adalah suatu 'alat' yang menghubungkan kita dengan dunia luar. Tanpa media, kita akan sulit mengetahui apa yang terjadi di sekeliling kita. Oleh karena itu dapat dikatakan bahwa media adalah sumber informasi utama bagi semua orang di dunia.

Media dapat digolongkan menjadi tiga menurut jenisnya, yaitu media cetak yang terdiri dari koran, majalah, dan lain sebagainya, media elektronik terdiri dari televisi dan radio, dan media online dengan perangkat internet. Tiga jenis media tadi juga mempunyai kekurangan dan kelebihannya berdasarkan kecepatan, biaya produksi, ketajaman berita, dan lain-lain. Kelebihan serta kekuranagan ketiga media tersebut adalah :

\section{Media Elektronik}

\section{Kelebihan :}

Cepat, dari segi waktu, media elektronik tergolong cepat dalam menyebarkan berita ke masyarakat luas. • Ada audio visual, media elektronik mempunyai audio visual yang memudahkan para audiensnya untuk memahami berita.(khusus televisi) • Terjangkau luas, media elektronik menjangkau masyarakat secara luas.

\section{Kekuranganya:}


Tidak ada pengulangan, media elektronik tidak dapat mengulang apa yang sudah ditayangkan.

\section{Media Online}

Kelebihan :

1. Sangat cepat, dari segi waktu media online sangat cepat dalam menyampaikan beritanya.

2. Audio Visual, media online juga mempunyai audio visual dengan melakukan streaming.

3. Praktis dan Fleksibel, media online dapat diakses dari mana saja dan kapan saja yang kita mau.

\section{Kekurangan :}

Tidak selalu tepat, karena mengutamakan kecepatan berita yang dimuat di media online biasanya tidak seakurat media lainnya.

\section{B. Tinjauan Tentang Industri}

Media Wajah industri media di Indonesia diwarnai semangat ekspansionis dari para pelaku bisnis media. Beberapa kelompok usaha media melebarkan sayap bisnisnya dengan menerbitkan media baru: cetak dan eletronik (dengan mendirikan stasiun televisi lokal yang baru; atau mengakuisisi stasiun radio atau media lainnya). Pemilik dan pengelola stasiun TV masuk ke media cetak, Sebaliknya pemilik dan pengelola media cetak juga tak mau ketinggalan ikut mendirikan stasiun televisi. Tak cukup sampai disitu. Mereka juga merambah untuk memiliki sejumlah media sekaligus: suratkabar, tabloid, situs berita, stasiun radio dan televisi - bahkan membuat rumah produksi (media tayang) atau kantor berita (media cetak).

Di beberapa daerah, bahkan ada yang sampai memiliki dua hingga empat stasiun televisi. Soal kepemilikannya: ada yang murni swasta, ada yang ditopang oleh BUMN yang kebetulan beroperasi di wilayah tersebut, dan ada juga yang dibiayai (sebagian) anggaran Pemerintah Daerah dan dikelola oleh swasta. Jumlah televisi lokal diprediksi akan terus bertambah karena UU No.32/2002 tentang Penyiaran membuka peluang pengusaha membangun stasiun televisi baru. 
Lahirnya UU Penyiaran juga telah membatasi televisi swasta untuk melakukan siaran secara nasional. Penegasan hal ini tercantum dalam Pasal 20 yang menyebutkan, "Lembaga Penyiaran Swasta jasa penyiaran radio dan jasa penyiaran televisi masingmasing hanya dapat menyelenggarakan 1 (satu) siaran dengan 1 (satu) saluran siaran pada 1 (satu) cakupan wilayah siaran." Pasal tersebut menyatakan bahwa di Indonesia akan dikembangkan sebuah sistem penyiaran yang mendasarkan dirinya pada dan dengan kehadiran stasiun penyiaran jaringan dan stasiun penyiaran lokal.

Dengan demikian, terbuka peluang munculnya keragaman tayangan televisi, peluang masyarakat lokal menikmati siaran tentang segala hal yang terkait erat dengan kehidupan di tempat mereka tinggal. Namun kenyataan bahwa Indonesia masih dalam keadaan ekonomi yang sangat sulit, tidak mudah mencari penduduk lokal yang dapat dan mau mendirikan stasiun televisi lokal komersial dengan investasi besar. Hal ini tentu berbeda dengan mendirikan stasiun radio yang dalam kenyataannya di Indonesia saat ini memang sudah mayoritas bersifat lokal. Maka itu adalah hal yang adil jika nanti stasiun swasta televisi nasional yang ingin beroperasi secara nasional harus berubah menjadi stasiun televisi jaringan. Dan ini tentunya memberikan kemungkinan untuk ikut tumbuh dan berkembangnya stasiun televisi lokal. Format televisi jaringan bukan hanya menyangkut daya jangkau siaran televisi swasta dan lokal di seluruh Indonesia, tetapi juga jaringan bisnis yang ter- diversifikasi pada beberapa sektor. Hal ini penting untuk menunjang daya tahan stasiun televisi swasta menghadapi kompetisi. (Dikutip dari Makalah Mencermati Bisnis Televisi Lokal di Indonesia 2009 oleh Aulia Andri).

\section{Tinjauan Tentang KPI dan KPID}

Komisi Penyiaran Indonesia (KPI) adalah sebuah lembaga independen di Indonesia yang kedudukannya setingkat dengan lembaga negara lainnya yang berfungsi sebagai regulator penyelenggaraan penyiaran di Indonesia. Komisi ini berdiri sejak tahun 2002 berdasarkan Undang-undang Republik Indonesia Nomor 32 Tahun 2002 Tentang Penyiaran. Komisi Penyiaran Indonesia Daerah atau KPID adalah sebuah lembaga negara independen di Indonesia yang didirikan di setiap provinsi berfungsi sebagai regulator penyelenggaraan penyiaran di setiap Provinsi di 
Indonesia. Dasar hukum pembentukannya adalah Undang-undang Republik Indonesia Nomor 32 Tahun 2002 Tentang Penyiaran.

\section{Tugas Pokok KPID}

Mengenai tugas, kewajiban, fungsi dan wewenang KPI/KPID dapat dikelompokkan dalam tiga kegiatan yaitu

a. Regulasi/pengaturan,

b. Pengawasan Dalam hal ini pengawasan yang dimaskud adalah pengawasan terhadap lemabaga penyiaran baik dari isi siaran maupun izin penyelenggaraan penyiaan.

c. Pengembangan

\section{Tugas dan Kewajiban KPID}

KPID mempunyai tugas dan kewajiban :

a. menjamin masyarakat untuk memperoleh informasi yang layak dan benar sesuai dengan hak asasi manusia;

b. ikut membantu pengaturan infrastruktur bidang penyiaran;

c. ikut membangun iklim persaingan yang sehat antar lembaga penyiaran dan industri terkait;

d. memelihara tatanan informasi nasional yang adil, merata, dan seimbang;

e. menampung, meneliti, dan menindaklanjuti aduan, sanggahan, serta kritik dan apresiasi masyarakat terhadap penyelenggaraan penyiaran; dan menyusun perencanaan pengembangan sumber daya manusia yang menjamin profesionalitas di bidang penyiaran

\section{Fungsi dan Wewenang KPID}

Dalam menjalankan fungsi, tugas, wewenang dan kewajibannya, KPI Pusat diawasi oleh Dewan Perwakilan Rakyat Republik Indonesia, dan KPI Daerah diawasi oleh Dewan Perwakilan Rakyat Daerah Provinsi.

a. Pasal 8 (1) KPI sebagai wujud peran serta masyarakat berfungsi mewadahi aspirasi serta mewakili kepentingan masyarakat akan penyiaran.

b. Pasal 8 (2) Dalam menjalankan fungsinya sebagaimana dimaksud dalam ayat (1), KPI mempunyai wewenang: 
c. menetapkan standar program siaran;

d. menyusun peraturan dan menetapkan pedoman perilaku penyiaran;

e. mengawasi pelaksanaan peraturan dan pedoman perilaku penyiaran serta standar program siaran;

f. memberikan sanksi terhadap pelanggaran peraturan dan pedoman perilaku penyiaran serta standar program siaran;

g. melakukan koordinasi dan/atau kerjasama dengan Pemerintah, lembaga penyiaran, dan masyarakat. (UUP No.32/2002 pasal 7)

\section{Tinjauan Tentang Perizinan}

Perizinan Perizinan adalah simpul utama dari pengaturan mengenai penyiaran. Dalam rangkaian daur proses pengaturan penyiaran, perizinan menjadi tahapan keputusan dari negara (melalui KPI) untuk memberikan penilaian (evaluasi) apakah sebuah lembaga penyiaran layak untuk diberikan atau layak meneruskan hak sewa atas frekuensi. Dengan kata lain, perizinan juga menjadi instrumen pengendalian tanggungjawab secara kontinyu dan berkala agar setiap lembaga penyiaran tidak melenceng dari misi pelayanan informasi kepada publik. Dalam sistem perizinan diatur berbagai aspek persyaratan, yakni mulai persyaratan perangkat teknis (rencana dasar teknik penyiaran dan persyaratan teknis perangkat penyiaran, termasuk jaringan penyiaran), substansi/format siaran (content), permodalan (ownership), serta proses dan tahapan pemberian, perpanjangan atau pencabutan izin penyelenggaraan penyiaran.

\section{Izin Prinsip dan Izin Stasiun Radio}

Izin Prinsip adalah hak yang diberikan oleh negara melalui KPI kepada lembaga penyiaran khususnya televisi untuk melakukan uji coba siaran sesuai dengan

penjelasan Peraturan Pemerintah tentang penyelenggaraan penyiaran. Setelah memperoleh izin prinsip, izin prinsip ini digunakan untuk mengurus proses penetapan frekuensi berupa izin stasiun radio (ISR).

Izin Stasiun Radio (ISR) adalah izin yang dikeluarkan oleh Ditjen Postel kepada lembaga penyiaran baik radio maupun televisi setelah memperoleh izin prinsip. ISR ini di gunakan untuk mengurus sertifikasi alat. Setelah memiliki ISR 
dan sertifikasi alat, lembaga penyiaran bisa mengajukan kepada KPI untuk melakukan uji coba siaran.

\section{Izin Penyelenggaraan Penyiaran}

Izin Penyelenggaraan Penyiaran adalah hak yang diberikan oleh KPI kepada lembaga penyiaran untuk menyelenggarakan penyiaran. (www.kpi.go.id di akses tanggal 20 Agustus 2010) Izin Penyelenggaraan Penyiaran televisi swasta lokal, prosedurnya sama dengan lembaga penyiaran yang lainnya. Sebelum menyelenggarakan kegiatannya lembaga penyiaran wajib memperoleh izin penyelenggaraan penyiaran. Langkahlangkah yang harus ditempuh untuk memperoleh IPP diantaranya :

1. Pengajuan proposal ke KPID.

2. Verifikasi Administrasi oleh KPID.

3. Verifikasi Faktual di lokasi penyiaran.

4. Evaluasi Dengar Pendapat

5. Rapat pleno KPID untuk memutuskan rekomendasi kelayakan.

6. Rekomendasi kelayakan dikirim ke KPI Pusat dan Depkominfo.

7. Pra Forum Rapat Bersama.

8. Forum Rapat Bersama.

9. Keputusan Rapat bersama dan dikeluarkannya IPP.

\section{E. Tinjauan Tentang Penyiaran}

\section{a. Siaran.}

Siaran adalah pesan atau rangkaian pesan dalam bentuk suara, gambar atau suara dan gambar atau yang berbentuk grafis, karakter, baik yang bersifat interaktif maupun tidak, yang dapat diterima melalui perangkat penerima siaran.

\section{b. Penyiaran}

Penyiaran adalah kegiatan pemancarluasan siaran melalui sarana pemancaran dan atau sarana transmisi di darat, di laut atau di antariksa dengan menggunakan spektrum frekuensi radio melalui udara, kabel, dan atau media lainnya untuk dapat 
diterima secara serentak dan bersamaan oleh masyarakat dengan perangkat penerima siaran.

\section{c. Lembaga Penyiaran}

Lembaga penyiaran adalah penyelenggara penyiaran, baik lembaga penyiaran publik lembaga penyiaran swasta, lembaga penyiaran komunitas maupun lembaga penyiaran berlangganan yang dalam melaksanakan tugas, fungsi, dan tanggung jawabnya berpedoman pada peraturan perundang-undangan yang berlaku. (UUP No.32 Tahun 2002 pasal 1) Penyiaran berasal dari kata siar, siar yang berarti menyebarluaskan informasi melalui pemancar, kata siar ditambah dengan akhiranan, membentuk kata benda siaran yang menurut UUP 32/2002 adalah pesan atau rangkaian pesan dalam bentuk suara dan gambar atau yang berbentuk grafis, karakter, baik yang bersifat interaktif maupun tidak, yang dapat diterioma melalui perangkat penerima siaran.

Siaran dapat berupa audio seperti radio, dan dapat pula siaran audio visual gerak dan sinkron seperti televisi (Morissan, 2005:23). Adapun kegiatan penyiaran itu sendiri meliputi

1. Merencanakan dan memproduksi acara.

2. Mengadakan atau menyiapkan program.

3. Menyiapkan pola acara, baik harian, mingguan, bulanan, triwulan, tengah bulan, dan seterusnya.

4. Menyelenggarakan siaran, baik artistik maupun jurnalistik.

5. Mengadakan kerjasama dengan lembaga penyiaran lain.

6. Mengadakan kerjasama dengan production house.

7. Mengadakan penelitian dan pengembangan.

8. Mengadakan pendidikan dan pengembangan siaran.

9. Menyelenggarakan pertukaran berita dan program dengan lembaga penyiaran baik dari dalam maupun luar negeri.

10. Mengadakan promosi dan penjualan program. (Morissan,2005:25)

\section{F.Tinjauan Tentang Penyiaran Televisi}


Penyiaran televisi adalah media komunikasi massa dengar pandang, yang menyalurkan gagasan dan informasi dalam bentuk suara dan gambar secara umum, baik terbuka maupun tertutup, berupa program yang teratur dan berkesinambungan.

\section{Penyiaran Televisi di Indonesia}

Televisi yang pada mulanya dipandang sebagai barang mainan atau suatu penemuan serius atau suatu yang memberikan sumbangan terhadap kehidupan sosial, kemudian berperan sebagai alat pelayanan. Pada intinya, televisi lahir dengan memanfaatkan semua media yang sudah ada sebelumnya. Hal terpenting lainnya dalam sejarah perkembangan televisi ialah ketatnya peraturan, pengendalian atau pemberian izin yang dilakukan oleh pengusaha (Kusnadi, 1996:7) Komunikasi massa media televisi adalah proses komunikasi antara komunikator dan komunikan (massa) melalui sebuah sarana, yaitu televisi.

\section{Program Siaran Televisi di Indonesia}

Stasiun televisi setiap harinya menyajikan berbagai jenis program siaran televisi yang jumlahnya sangat banyak dan jenisnya sangat beragam. Pada dasarnya apa saja bisa dijadikan materi siaran untuk ditayangkan di televisi selama program itu menarik dan disukai audiens, dan selama tidak bertentangan dengan kesusilaan, hukum dan peraturan yang berlaku. Pengelola stasiun penyiaran dituntut untuk memiliki kreativitas seluas mungkin untuk menghasilkan berbagai program yang menarik.

Berbagai jenis itu dapat dikelompokkan menjadi dua bagian besar berdasarkan jenisnya yaitu program informasi (berita) dan program hiburan (entertaiment). Program informasi kemudian dibagi lagi menjadi dua jenis yaitu berita keras (hard news) yang merupakan laporan berita terkini yang harus segera disiarkan dan berita lunak (soft news) yang merupakan kombinasi dari fakta, gosip, dan opini.

\section{Penyiaran Televisi Swasta Lokal di Indonesia}

Televisi swasta lokal adalah media komunikasi massa dengar pandang yang menyalurkan gagasan dan informasi dalam bentuk suara dan gambar secara umum, baik terbuka maupun tertutup, berupa program yang diatur dan berkesinambungan, 
dan bersifat komersial berbentuk badan hukum Indonesia, yang bidang usahanya hanya menyelenggarakan jasa penyiaran televisi dan jangkauannya hanya terbatas pada daerah tertentu.

\section{a. Perkembangan Televisi Lokal}

Pada perjalanannya dari awal hingga saat ini, UU No. 32/2002 tentang penyiaran belum mendapatkan kejelasan yang pasti, terutama yang mengatur mengenai batas wilayah siaran yang mengisyaratkan bahwa TV nasional untuk mengurangi kapasitas dan wilayah jangkauannya. Banyak pihak yang menentang UU ini terutama dari kalangan pemilik TV swasta yang sudah terlanjur menanamkan investasi yang tinggi untuk televisinya, UU tersebut dimaknai akan membatasi ruang bisnis mereka.

Karena munculnya pertentangan, akibatnya hingga kini UU penyiaran tersebut masih belum jelas kekuatannya. Terlepas dari konflik kepentingan antara pemerintah dan kapitalisme industri pertelevisian yang ada, TV lokal kemudian lahir dengan gairah otonomi daerah yang ada. Semangat untuk menjadi media lokal yang memfasilitasi masyarakat daerah masing-masing, baik dari segi informasi ataupun hiburan seakan menjadi jargon yang memposisikan TV lokal sebagai prospek cerah bagi kemajuan dunia media di Indonesia. Sebagaimana kedudukannya sebagai media daerah, maka dalam penyajian dan kemasannnya pun TV lokal cenderung menampilkan dan mengedepankan permasalahan daerah, baik dari isu yang dibawa maupun dari bahasa yang digunakan.

Selain pemakaian bahasa, dalam isi pemberitaan juga program acaranya TV lokal terfokus membahas permasalahan lokal daerah masing-masing. Walaupun mempunyai ciri khas dari segi pengemasan isu maupun bahasa, pada perkembangannya TV lokal masih belum mampu untuk menjadi alternatif dari TV-TV nasional yang telah dulu mengudara. Hal itu bisa dilihat dari format acara yang cenderung sama, daya kreatif yang diharapkan belum mampu dipenuhi secara inovatif. Fenomena ekor mengekor dalam dunia pertelevisian sebenarnya bukan hal yang asing, hal ini tidak hanya terjadi pada TV lokal tapi pada kenyataannya terjadi pula diantara TV nasional itu sendiri. Keterbatasan investasi 
dan lemahnya daya saing terhadap TV nasional menjadi kendala tersendiri bagi TV lokal untuk bersaing dengan TV nasional, hal ini kemudian mengakibatkan TV lokal kesulitan di dalam mengembangkan dirinya.

\section{b. Popularitas Televisi Lokal}

Popularitas TV lokal ditengah masyarakat yang kalah jauh dibanding TV nasional menjadi faktor bagi minimnya sponsor dan investasi pengiklan untuk ikut menghidupi TV lokal. Faktor modal adalah salah satu kendala yang membatasi kinerja dari sebagian besar TV lokal yang ada dewasa ini, namun jika pemerintah dalam hal ini lebih tegas dalam mengatur dan menjalankan regulasi seperti yang tercakup dalam UU penyiaran yang mengatur wilayah siaran maka sedikit banyaknya perkembangan TV lokal akan terbantu, karena konsentrasi TV lokal baik dari segmentasi pasar maupun iklan akan terjaga. Media, seperti dalam bentuk TV harus dipandang sebagai alat untuk mencerdaskan masyarakat, bukan aspek bisnis semata. Seiring berkembangnya dunia pertelevisian di Indonesia maka semakin banyak pula stasiun televisi yang bermunculan.

Dari asalnya hanya stasiun televisi milik pemerintah yaitu TVRI, lalu berkembang dan bermunculan berbagai stasiun televisi swasta nasional. Seiring berjalannya waktu perkembangan dunia pertelevisian di Indonesia pun berkembang ditandai dengan bermunculannya barbagai televisi lokal yang siaranya tidak berskala nasional, tetapi hanya berskala lokal. (http://fauzyalfalasany.blogspot.com/2010/01/perkembangan-tv-lokal.html diakses tanggal 7 September 2010)

Berdasarkan uraian di atas, diketahui bahwa kalangan fungsional memandang masyarakat sebagai berikut.

1. Masyarakat dipandang sebagai suatu jaringan kelompok yang bekerja sama secara terorganisasi yang bekerja dalam suatu cara yang agak teratur menurut seperangkat peraturan dan nilai yang dianut oleh sebagian besar masyarakat tersebut.

2. Masyarakat dipandang sebagai suatu sistem yang stabil dengan kecenderungan kearah keseimbangan, yaitu suatu kecenderungan untuk mempertahankan sistem kerja yang selaras dan seimbang. 
3. Setiap kelompok atau lembaga melaksanakan tugas tertentu dan terus menerus, karena hal itu fungsional.

4. Corak perilaku timbul karena secara fungsional bermanfaat. (Sutaryo, 1992:7)

Menurut teori struktural fungsional, masyarakat sebagai suatu sistem memiliki struktur yang tediri atas banyak lembaga. Masing-masing lembaga memiliki fungsi sendiri-sendiri. Struktur dan fungsi, dengan kompleksitas yang berbeda- beda, ada pada setiap masyarakat, baik masyarakat modern maupun masyarakat modern maupun masyarakat primitif. Misalnya, lembaga sekolah mempunyai fungsi mewariskan nilainilai yang ada kepada generasi baru. Lembaga keluarga berfungsi menjaga kelangsungan perkembangan jumlah penduduk. Lembaga politik berfungsi menjaga tatanan sosial agar berjalan dan ditaati sebgaimana mestinya.

Semua lembaga tersebut akan saling berinteraksi dan saling menyesuaikan yang mengarah pada keseimbangan. Bila terjadi penyimpangan dari sutu lembaga masyarakat maka lembaga yang lainnya akan membantu dengan mengambil langkah penyesuaian. (Zamroni, 1988:27) Antara aktor dengan berbagai motif dan nilai yang berbeda-beda menimbulkan tindakan yang berbeda-beda. Bentuk-bentuk interaksi dikembangkan sehingga melembaga. Pola-pola pelembagaan tersebut akan menjadi sistem sosial. Untuk menjaga kelangsungan hidup suatu masyarakat, setiap masyarakat perlu melaksanakan sosialisasi system social yang dimiliki.

\section{Pandangan Talcott Parsons tentang Fungsionalime}

Pada awalnya Parsons mengkritik paham Utilitarianisme yang berpendapat bahwa individu sebagai aktor yang atomistik, cenderung berlaku rasional, dan memunculkan ide-ide konstruksionalisme dalam integrasi sosial. Parsons lebih banyak mengkaji perilaku individu dala integrasi sosial. Parsons lebih banyak mengkaji perilaku individu dalam organisasi system sosial hingga melahirkan teori tindaklan sosial atau Social Action. Posisi individu dalam sistem sosial selalu memiliki status dan perannya masing-masing. Dalam sistem sosial, individu menduduki suatu tempat (status) dan bertindak sesuai norma atau aturan-aturan yang dibuat oleh sistem yang ada. 
Di dalam setiap masyarakat, menurut pandangan fungsionalisme struktural, selalu terdapat tujuan-tujuan dan prinsip-prinsip dasar tertentu. Sistem nilai tersebut tidak saja merupakan sumber yang menyebabkan berkembangnya integrasi sosial, akan tetapi sekaligus merupakan unsur yang menstabilisir sosial budaya itu sendiri. (Nasikun: 1995).

\section{Fungsi Utama Media Massa}

Bagi Masyarakat Kerangka acuan yang telah disinggung terdahulu menunjukkan beberapa kemungkinan mengenai fungsi yang melekat pada media dalam melakukan perannya sebagai saluran mediasi. Pendekatan functionalism umumnya diyakini sangat bermanfaat untuk melihat upaya saling keterkaitan antara media massa dengan institusi-institusi lain dalam masyarakat termasuk pemerintah, partai poitik, dan keluarga. Harold D. Lasswell (1948/1960), pakar komunikasi dan professor hukum di Yale mencatat ada tiga fungsi media massa : pengamatan lingkungan, korelasi bagian-bagian dalam masyarakat untuk merespon lingkungan, dan penyampaian warisan masyarakat dari satu generasi ke generasi selanjutnya.

\section{H. Kerangka Pikir}

Saat ini selain sudah ada 14 stasiun swasta yang berbasis di Jakarta dengan jangkauan nasional, juga banyak bermunculan televisi swasta lokal dengan jangkauan yang terbatas di sebuah wilayah provinsi atau kabupaten. Dalam dunia penyiaran khususnya penyiaran televisi perlu adanya pengawasan dari suatu lembaga yaitu Komisi Penyiaran Indonesia baik pusat maupun daerah. Komisi Penyiaran Indonesia Daerah atau KPID adalah sebuah lembaga negara independen di Indonesia yang didirikan di setiap provinsi berfungsi sebagai regulator penyelenggaraan penyiaran di setiap Provinsi di Indonesia. KPID merupakan sebuah lembaga yang mampu menjadi kontrol terhadap media terutama menyangkut Izin Penyelenggaraan Penyiaran.

KPID mempunyai tugas dan fungsi diantaranya menetapkan standar program siaran, menyusun peraturan dan menetapkan pedoman perilaku penyiaran, mengawasi pelaksanaan peraturan dan pedoman perilaku penyiaran serta standar program siaran, memberikan sanksi terhadap pelanggaran peraturan dan pedoman perilaku penyiaran serta standar program siaran, dan melakukan koordinasi dan/atau kerjasama dengan 
Pemerintah, lembaga penyiaran, dan masyarakat. Izin Penyelenggaraan Penyiaran (IPP) adalah hak yang diberikan oleh KPID kepada lembaga penyiaran untuk menyelenggarakan penyiaran. Sebelum memperoleh izin penyelenggaraan penyiaran televisi lokal harus melengkapi persyaratan yang diperlukan untuk diajukan ke KPID. Setelah persyaratan lengkap, televisi swasta lokal selanjutnya bisa meneruskan ke tahap-tahap untuk memperoleh IPP. Dengan IPP ini, lembaga penyiaran khususnya televisi bersiaran secara legal. Selain legal, lembaga penyiaran pun harus aman. Supaya aman, lembaga penyiaran itu harus menjalankan program yang tidak melanggar aturan. Yakni sesuai dengan P3SPS (Pedoman Perilaku Penyiaran dan Standar Program Siaran).

\section{Bagan.I. Kerangka Pikir}

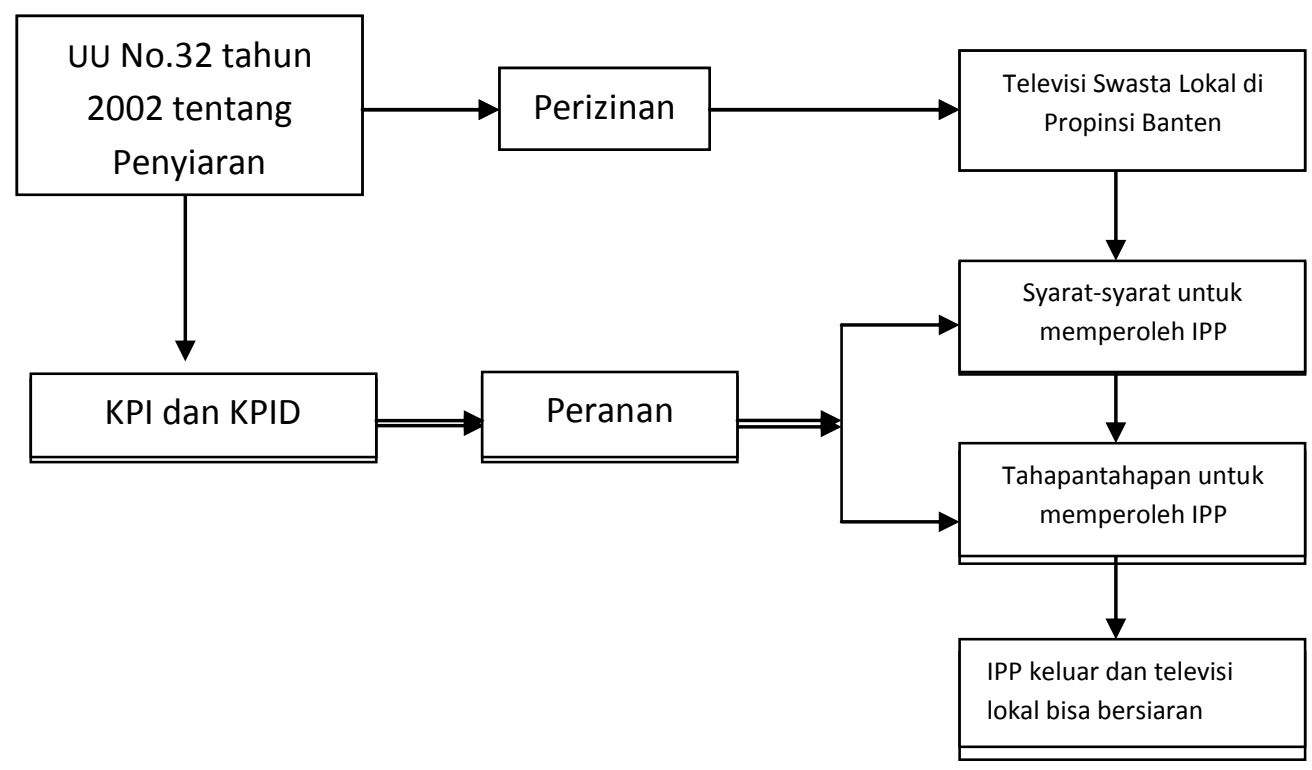

\section{METODOLOGI DAN TIPE PENELITIAN}

Tipe penelitian yang digunakan dalam penelitian ini adalah tipe penelitian deskriptif. Tipe penelitian deskriptif dirancang untuk mengumpulkan informasi tentang keadaan-keadaan nyata sekarang (sementara berlangsung). Tujuan utama dalam menggunakan metode ini adalah untuk menggambarkan sifat suatu keadaan 
yang sementara berjalan pada saat penelitian dilakukan, dan memeriksa sebabsebab dari suatu gejala tertentu (Consuelo dkk, 1993: 71).

Sedangkan menurut Whitney dalam Nazir (1988: 63), metode penelitian deskriptif adalah pencarian fakta dengan interprestasi yang tepat. Penelitian deskriptif mempelajari masalah-masalah dalam masyarakat, serta tata cara yang berlaku dalam masyarakat serta situasi-situasi tertentu, termasuk tentang hubungan, kegiatan-kegiatan, sikap-sikap, pandangan-pandangan, serta proses-proses yang sedang berlangsung dan pengaruh-pengaruh dari suatu fenomena. Penelitian deskriptif mempunyai ciri-ciri:

1. Berhubungan dengan keadaan yang terjadi saat itu

2. Menguraikan satu variabel saja atau beberapa variabel namun diuraikan satu per satu

3. Variabel yang diteliti tidak dimanipulasi atau tidak ada perlakuan (Kountur, 2003: 105-106).

\section{A. Metode Penelitian}

Metode yang digunakan dalam penelitian ini metode penelitian dengan pendekatan kualitatif. Pengertian penelitian kualitatif menurut Miles dan Huberman (1992: 6) dalam Basrowi Sudikin menyatakan bahwa salah satu prosedur penelitian yang dihasilkan data deskriptif berupa ucapan atau tulisan dan prilaku orang-orang yang diamati. Melalui penelitian kualitatif, peneliti dapat mengenali subjek dan merasakan apa yang mereka alami dalam kehidupan sehari- hari.

Penelitian ini merupakan studi yang mengkaji mengenai "Peranan Komisi Penyiaran Indonesia Daerah Provinsi Banten dalam Mengawasi Izin Penyelenggaraan Penyiaran Pada Lembaga Penyiaran Televisi Swasta Lokal di Propinsi Banten" yaitu suatu bentuk penelitian yang bertujuan untuk menggambarkan atau mendeskripsikan secara terperinci mengenai fenomena tertentu sehingga dapat ditarik sebuah kesimpulan dan juga merupakan cara yang digunakan untuk menggambarkan suatu situasi atau populasi tertentu yang bersifat faktual secara sistematis dan aktual. Dengan kata lain, tujuan penelitian deskriptif 
adalah menggambarkan seperangkat peristiwa atau kondisi populasi saat ini. Sedangkan menurut G. Tan penelitian deskriptif bertujuan untuk menggambarkan secara tepat sifat-sifat suatu individu, keadaan, gejala atau kelompok tertentu atau menentukan frekuensi atau penyebaran suatu gejala adanya hubungan tertentu antara satu gejala dengan gejala lain dalam masyarakat. (Koentjaraningrat, 1973 :3).

Penelitian ini akan berusaha untuk menjelaskan, mengelola, menggambarkan dan menafsirkan hasil penelitian dengan penyusunan kata-kata menjadi uraian kalimat-kalimat sebagai jawaban atas permasalahan yang akan diteliti serta melalui data deskriptif kualitatif ini kita bisa memahami dan mengikuti alur peristiwa secara kronologis, menilai sebab akibat dan memperoleh berbagai fakta dan data.

\section{B. Fokus Penelitian}

Fokus penelitian dalam penelitian ini menitikberatkan pada bagaimana peranan Komisi Penyiaran Indonesia Daerah Provinsi Banten dalam mengawasi izin penyelenggaraan penyiaran pada lembaga penyiaran televisi swasta lokal di Propinsi Banten.

Selain itu, aspek-aspek yang akan dibahas diantaranya : - Syarat-syarat yang harus dipenuhi lembaga penyiaran televisi swasta lokal untuk mendapatkan IPP. Syarat yang harus dipenuhi untuk memperoleh IPP diantaranya :

1. Berbentuk PT

2. Dimiliki orang daerah

3. Konsentrasi modal oleh satu orang

4. Infrastruktur

5. Surat keterangan domisili

6. Ada studi kelayakan.

7. Ada SITU/SIUP, Tanda Daftar Perusahaan, NPWP, IMB, dan ISR -

Tahapan Izin Penyelenggaraan Penyiaran Izin Penyelenggaraan Penyiaran adalah hak yang diberikan oleh KPI kepada lembaga penyiaran untuk menyelenggarakan penyiaran Proses dan tahapan, pemberian dan perpanjangan izin penyelenggaraan penyiaran akan diberikan oleh negara setelah memperoleh:

1. Masukan dan hasil evaluasi dengar pendapat antara pemohon dan KPID; 
2. Rekomendasi kelayakan penyelenggaraan penyiaran dari KPID;

3. Hasil kesepakatan dalam forum rapat bersama yang diadakan khusus untuk perizinan antara KPID dan Pemerintah; dan izin alokasi dan penggunaan spektrum frekuensi radio oleh Pemerintah atas usul KPID.

\section{Lokasi Penelitian}

Penelitian ini dilaksanakan di Komisi Penyiaran Indonesia Daerah Provinsi Banten. Lokasi penelitian ini beralamatkan di Jl. Syekh Moh. Nawawi Albantani No.16, Banjarsari, Cipocok Jaya, Kota Serang, Banten 42123. Selain itu untuk melengkapi data yang diperlukan, peneliti juga memilih lokasi di stasiun televisi swasta lokal yang ada di Propinasi Banten, yaitu Hendarto Setiawan, S.H (Pimpinan Redaksi Radar TV), Edi Purwanto (Direktur Utama Tegar TV), Yacob Hendro (Direktur Utama Krakatau TV), dan Drs. H. Aries Wijayanto H.S (Direktur Utama Siger TV).

\section{Penentuan Informan}

1. Menurut Spardly dalam Faisal (1990: 45) informan harus memenuhi beberapa kriteria yang perlu dipertimbangkan yaitu :

a. Subjek yang telah lama dan intensif menyatu dengan satu kegiatan atau aktivitas yang menjadi sasaran atau perhatian penelitian, dan ini biasanya ditandai oleh kemampuan memberikan informasi diluar kepala tentang sesuatu yang ditanyakan.

b. Subjek masih terikat secara penuh serta aktif pada lingkungan dan kegiatan yang menjadi sasaran atau penelitian. 3. Subjek mempunyai cukup banyak waktu dan kesempatan untuk dimintai informasi. Informan merupakan sumber informasi atau data yang akan ditelusuri, dicari dan dihubungi peneliti. Atas dasar itulah maka peranan informan sangat berpengaruh dan penting dalam rangka proses pengumpulan fakta.

2. Adapun informan yang dipilih dalam penelitian ini dipertimbangkan melalui kriteria-kriteria antara lain sebagai berikut : 
a. Memiliki pengetahuan yang luas di bidang penyiaran. Dalam hal ini informan mempunyai pengetahuan luas tentang penyiaran baik televisi maupun radio. Informan yang dimaksud adalah Komisioner Bidang Perizinan KPID Provinsi Banten yang berjumlah dua orang.

b. Mengetahui prosedur-prosedur perizinan pada lembaga penyiaran televisi. Informan mengetahui langkah-langkah memperoleh izin siaran serta aktif dalam proses IPP untuk lembaga penyiaran. Informan yang dimaksud adalah Anggota Bidang Perizinan KPID Provinsi Banten.

c. Mempunyai wewenang tinggi di lembaga penyiaran. Dalam hal ini informan adalah pemilik atau pimpinan televisi swasta lokal di Propinsi Banten.

d. Bersedia menjadi informan. Berdasarkan kriteria-kriteria informan di atas, maka peneliti menetapkan jumlah informan sebagai berikut : - Informan utama, yaitu dari pihak Komisi Penyiaran Indonesia Daerah Provinsi Banten yang berjumlah 2 orang, diantaranya Ketua KPID Banten Ade Mujaremi, S.Pd.I, Wakil Ketua KPID Banten Ahmad Fahmi, S.Pd.I.

e. Informan pendukung, yaitu dari pihak Televisi Swasta Lokal diantaranya Hendarto Setiawan, S.H (Pimpinan Redaksi Radar TV), Edi Purwanto (Direktur Utama Tegar TV), Yacob Hendro (Direktur Utama Krakatau TV), dan Drs. H. Aries Wijayanto H.S (Direktur Utama Siger TV). Jadi jumlah informan pendukung ada 4 orang.

\section{Daftar Pustaka}

Abdulsyani. 1994. Sosiologi Skematika, Teori dan Terapan. Jakarta: Bumi Aksara.

Faisal. Sanapiah. 1990. Metode Penelitian Kualitatif. Penerbit Universitas Negeri Malang

Koentjaraningrat. 1973. Metode-Metode Penelitian Masyarakat. Edisi Ketiga. Jakarta: Gramedia Pustaka Utama.

Kountur, Ronny. 2003. Metode Penelitian Untuk Penulisan Skripsi dan Tesis. Jakarta: Penerbit PPM.

Kusnadi, Wawan. 1996. Komunikasi Massa. Jakarta: PT. Rineka Cipta. 
Lawer, Robert H. 1977. Perspective on Social Change. Edisi Indonesia

Terjemahan Alimudin. SU. 1989. Perspektif Tentang Perubahan Sosial. Jakarta: Bijna Aksara.

McQuail, D. 1987. Teori Komunikasi Massa: Suatu Pengantar. Jakarta: Erlangga.

Miles, M.B. \& Huberman, A.M. 1992. Analisis Data Kualitatif. Terjemahan oleh Tjetjep Roehndi Rohidi. Jakarta: Penerbit Universitas Indonesia.

Morissan, 2005. Media Penyiaran;Strategi Mengelola Radio dan Televisi. Tangerang: Ramdina Prakarsa.

Nasikun. 1995. Sistem Sosial Indonesia. Jakarta: CV. Rajawali.

Nazir, Mohammad. 1988. Metode Penelitian. Jakarta: Ghalia Indonesia.

Ritzer, George. 1988. Sosiologi Ilmu Pengetahuan Berparadigma Ganda. Penyadur Alimandan. Jakarta: Rajawali Press.

Sevilla, Consuelo. 1993. Pengantar Metode Penelitian. Jakarta: Penerbit Universitas Indonesia.

Soekanto, Soerjono. 2006. Sosiologi Suatu Pengantar. Jakarta: PT Raja Grafindo Persada.

Strauss and Corbin. 1990. Basic Of Qualitative Research: Grounded Of Theory Procedures and Technique. Newbury Park: Sage Publication.

Subagyo, P. Joko. 2006. Metode Penelitian Dalam Teori dan Praktek. Jakarta: Rineka Cipta.

Suharsimi, Arikunto. 2002. Prosedur Penelitian Suatu Pendekatan Revisi VI. Jakarta: Rineka Cipta. 2006.

Prosedur Penelitian, Suatu Pendekatan Praktik. Jakarta: Rineka Cipta.

Sutaryo. 1992. Dinamika Masyarakat dalam Perspektif Konflik. Diklat Kuliah.Yogyakarta: Fisipol UGM.

Tankard, J.W., and Severin. 2001. Teori Komunikasi: Sejarah, Metode, dan Terapan di Dalam Media Massa. Jakarta: Kencana

Wahidin dkk. 2006. Filter Komunikasi Media Elektronika. Yogyakarta: Pustaka Belajar.

Wahyudi, J.B. 2004. Media Komunikasi Massa. Jakarta: Rineka Cipta.

Continuing The Classical Tradition. Second Edition. New Jersey: Prentice- Hall,Inc. Englewood Cliffs.

Zamroni. 1992. Pengantar Pengembangan Teori Sosial. Yogyakarta: PT Tiara Wacana

\section{Sumber Lain :}

Undang-undang No.32 Tahun 2002 Tentang Penyiaran

www.kpi.go.id di akses tanggal 20 Agustus 2010. http:// komunikasi publik. multiply. com/journal/item/33/Mencermati_Bisnis_

Televisi_Lokal_di_Indonesia, Aulia Andri, diakses tanggal 17 September 2010. 
http://fauzyalfalasany.blogspot.com/2010/01/perkembangan-tv-lokal.html diakses tanggal 7 September 2010.

http://deniborin.multiply.com/journal/item/40/TV_Lokal_dan_Isu_Lokal_diakses tanggal 12 Desember 2010.

http://www.suarakomunitas.net/profil/jrkl/ diakses tanggal 12 Desember 2010. 